\title{
Samtskhe-Javakheti Region: A Neglected Keypoint for European Security of Energy Supply?*
}

\section{Utku Yapıci** $^{* *}$}

\begin{abstract}
:
It is no doubt that the rise of new energy actors in post-Soviet geographic space such as Azerbaijan, Kazakhstan, and Turkmenistan was welcomed by Western power centers. Those emerging actors were assessed as partners in diminishing Europe's energy dependence to a single supplier; the Russian Federation. In this context, the main Western initiatives to challenge Russian energy dominance regarding the Caspian Basin were the Baku-Tbilisi-Ceyhan (BTC) oil pipeline, and South Caucasus gas pipeline. These two strategic pipelines pass through the territories of SamtskheJavakheti region of Georgia - a tiny administrative unit adjacent to the Turkish city of Ardahan and Armenian city of Gyumri. Because of that, any political turmoil in that strategic region should easily turn into a factor endangering both already unsatisfactory regional stability and European energy security.

In this article, Samtskhe-Javakheti region's economic and demographic characteristics that make it unique and prone to instability are analyzed and European Union's Samtskhe-Javakheti policy is evaluated through the lens of security of energy supply. The conclusion of the paper is that, the European Union failed to establish influential cooperation mechanisms to avoid political and economic instabilities in this transit region. The European Union simply lacks a comprehensive regional plan compatible with the sociological and economic realities of SamtskeJavakheti.
\end{abstract}

Keywords: $\quad$ Samtskhe-Javakheti, Energy Security, Baku-Tbilisi-Ceyhan, South-Caucasus Pipeline, Armenians.

\footnotetext{
* An earlier version of this paper was presented at the II. Black Sea and Balkans Economic and Political Studies Symposium, November 9-13, 2015, Saint Petersburg, the Russian Federation.

** Assist. Prof. Dr., Adnan Menderes University Faculty of Economics and Administrative Sciences, Department of International Relations, uyapici@adu.edu.tr.
} 


\section{Introduction}

Despite recent drops in European energy consumption related to the ongoing economic troubles in the eurozone, Europe remains heavily dependent on fuel imports ${ }^{1}$. According to 2014 statistics, the European Union's import dependency is considerably high for crude oil (almost 90\%), natural gas $(66 \%)$, solid fuels $(42 \%)$ and nuclear fuel $(40 \%)^{2}$. Because of that, the energy security issue which has gained prominence in European political agenda since the early $2000 \mathrm{~s}^{3}$ - is not losing its importance.

Traditionally speaking, volatile prices and disruptions to supply were assigned as two basic indicators of security of energy supply ${ }^{4}$. In order to contend with those risks, energydependent states need alternative energy sources, diversification of their routes ${ }^{5}$, and instrumental mechanisms to avoid political and economic instabilities regarding their suppliers and transit countries. At this point, European Union's strong dependence to an external supplier; the Russian Federation complicates the European security of energy supply issue. According to 2013 statistics, six European Union states' single external supplier of natural gas was the Russian Federation. In 2013, the Russian Federation accounted for $39 \%$ of the European Union's natural gas imports. Similarly, one third of European Union's total crude oil imports were from the Russian Federation ${ }^{6}$. Therefore, as Edward H. Christie points out, the structure of the Euro-Asia energy nexus should best be illustrated by using the word European energy vulnerability ${ }^{7}$.

In this paper, two European initiatives to diminish its energy vulnerability; Baku-TbilisiCeyhan Pipeline (BTC) and South Caucasus Pipeline (SCP) are evaluated through a close look at a tiny region of Georgia at the crossroads of the East-West energy corridor: Samtskhe-Javakheti. The paper aims at analyzing the effectiveness and efficiency of the European Union's SamtskheJavakheti policy.

\section{Alternative Pipeline Projects Traversing the South Caucasus}

Since the collapse of the Soviet Union, South Caucasus has gradually increased its importance both as a source of and transit route for hydrocarbons ${ }^{8}$. The unproven, but possible or probable oil/gas reserve statistics show that, Caspian region would constitute nearly $17 \%$ of the world oil reserves and $12 \%$ of the world gas reserves ${ }^{9}$. Taking into consideration the importance of Caspian's potential reserves, the rise of new energy actors in this energy-abundant region such as Azerbaijan, Kazakhstan, and Turkmenistan was welcomed in the Western power centers. Those emerging actors were assessed as partners in bypassing Russian energy dominance. However, Russian energy dominance in East-West Energy Corridor has not expired yet thanks to Russia's large reserves and Soviet legacy pipeline infrastructure.

\section{Map 1: BTC}

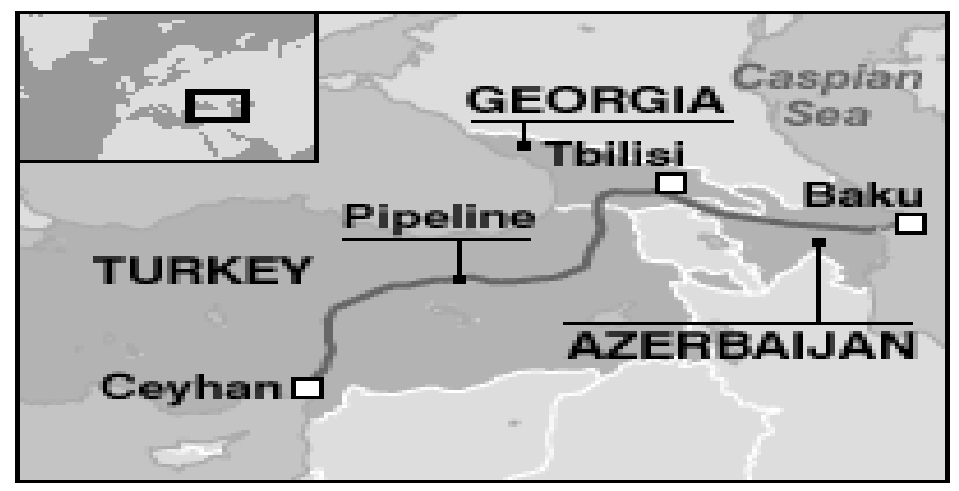

Source: http://news.bbc.co.uk/2/hi/business/4577497.stm.

The main Western initiative to challenge Russian energy dominance regarding the Caspian Basin was the Baku-Tbilisi-Ceyhan (BTC) oil pipeline (see. Map 1). Through the pipeline, Caspian oil has been transported from Azerbaijan via Georgia to Turkish port of Ceyhan 
in Mediterranean. The $1768 \mathrm{~km}$ pipeline, as the greatest private construction project in the world ${ }^{10}$ , was formally opened in July 2006. The export of Kazakh oil through the pipeline also started in 2013 in addition to the Azeri and Turkmenistan's oil ${ }^{11}$.

Likewise, a parallel gas pipeline - the $691 \mathrm{~km}$ South Caucasus Pipeline (SCP) (see. Map 2) - was opened in the same year. This parallel gas pipeline exports Shah Deniz gas from Azerbaijan to Georgia and Turkey ${ }^{12}$. In May 2014, a contact for South Caucasus Pipeline's (SCP) expansion was signed in Azerbaijan ${ }^{13}$. With the construction of Trans-Anatolian Natural Gas Pipeline Project (TANAP) and Trans-Adriatic Pipeline (TAP), it is expected that the transport of Caspian gas supplies from the Shah Deniz Gas Field to Europe will be accomplished in $2020^{14}$.

\section{Map 2: SCP, TANAP and TAP}

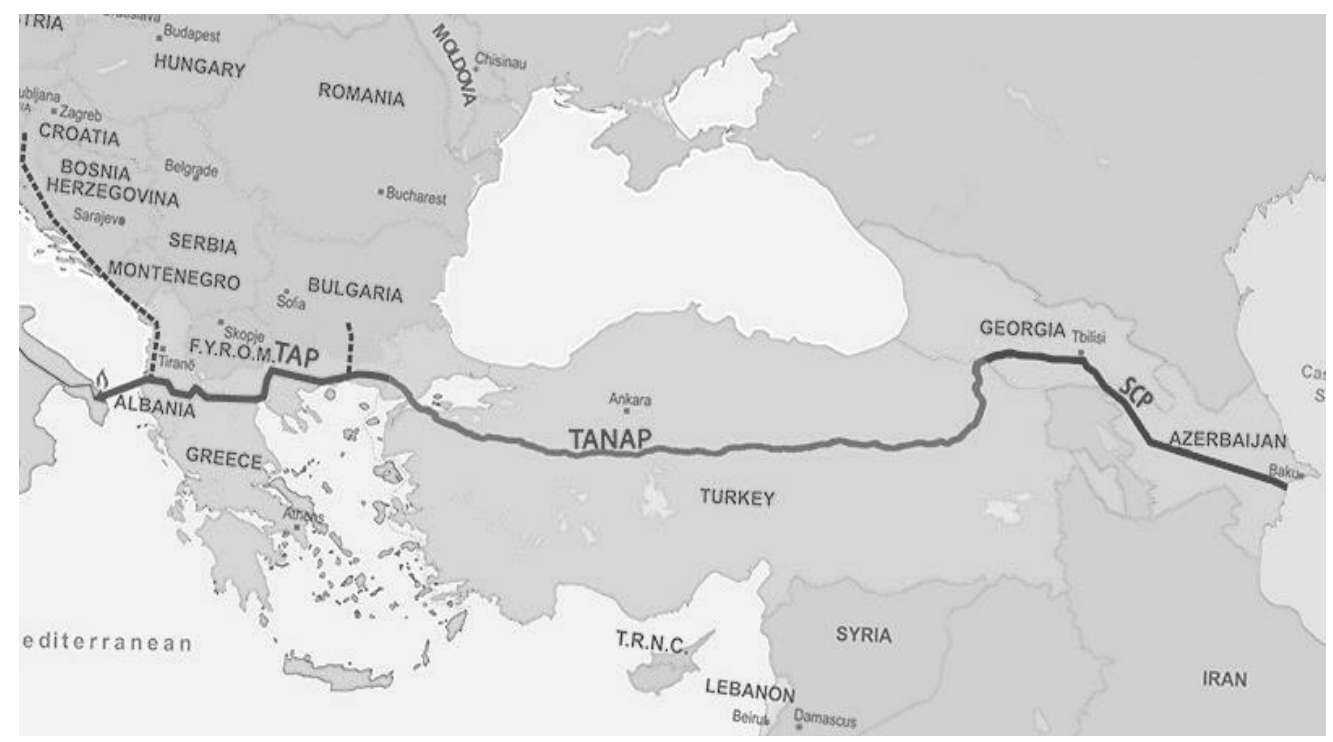

Source: http://www.tanap.com/.

\section{Samtskhe-Javakheti Region's Potential Impediments for European Security of Energy Supply}

The two strategic pipelines of the East-West energy corridor - BTC and SCP - pass through the territories of Samtskhe-Javakheti region of Georgia (see. Map 3) - a tiny administrative unit adjacent to the Turkish city of Ardahan and Armenian city of Gyumri. Because of that, any political turmoil in that strategic region should easily turn into a factor endangering both already unsatisfactory regional stability and European energy security.

Samtskhe-Javakheti region (see. Map 4) has interesting demographic, economic and political characteristics that make it unique and prone to instability. Firstly, a minority group Armenians - constitutes a demographic dominance in the region. However, the Armenians did not have a long history of settlement in the region - it was only in the $19^{\text {th }}$ century that widespread Armenian settlements began. After the Russo-Ottoman War of 1828-1829, the Armenians living mostly in Eastern Anatolia resettled massively to the territories of the Russian Empire, mostly in Yerevan, Akhaltsikhe and Akhalkalaki ${ }^{15}$. As Voitsekh Guretski points out, on the eve of the Bolshevik Revolution, Armenians constituted an absolute majority in Akhaltsikhe (82\%) and a slight majority in Akhalkalaki ${ }^{16}$. According to the 2002 Census, a total of 207598 people live in the Samtskhe-Javakheti region, out of which $54.6 \%$ are Armenians. In the Samtskhe part of the administrative entity of Samtskhe-Javakheti, Armenians constitute only $20.5 \%$ of the entire population. Armenians reach $36.6 \%$ in Akhaltsikhe, $17.5 \%$ in Aspindza, $10.1 \%$ in Borjomi and $3.4 \%$ in Adigeni. Correspondingly, in the two Javakheti districts Akhalkalaki and Ninotsminda, Armenians reach $94.3 \%$ and $95.8 \%$ respectively ${ }^{17}$. It should be noted that, due to the ethnic dominance of Armenians at least in the Javakheti half of the region and the region's proximity to 
Armenia, even the tenuous demands of Javakheti Armenians for autonomy or cultural rights eradicate Georgian fears of secession.

\section{Map 3: Samtskhe-Javakheti Region}

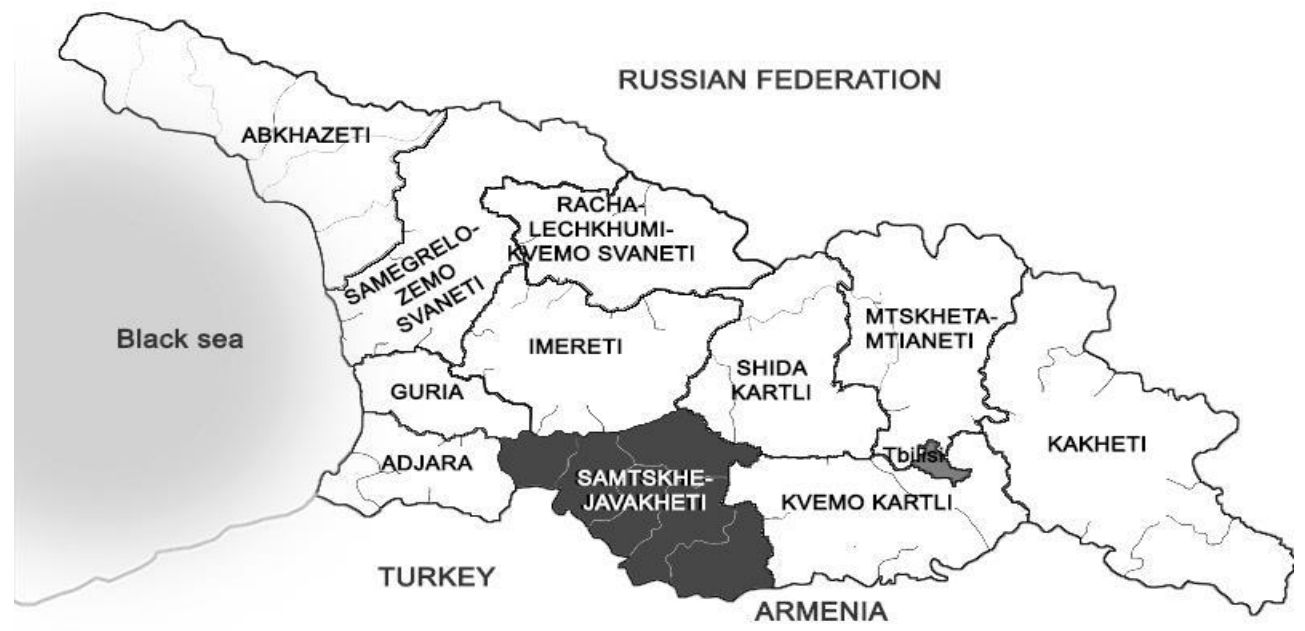

Source: $<\mathrm{http}: / /$ betravel.ge/index.php?hide=gejav\&lang=en.

Secondly, Samtskhe-Javakheti has always been Georgia's one of the poorest and unintegrated regions. Its underdeveloped infrastructure places it at a disadvantage compared to other regions of Georgia ${ }^{18}$. Standards of healthcare in the region are below the Georgian mean and alarming. Likewise, in Samtskhe-Javakheti, the percentage of the applicants pass the United National exams successfully and get enrolled in the universities is lower than in other regions of Georgia $^{19}$. On the other hand, this region has always been an agricultural land and suffered from low levels of industrialization. The share of agriculture in regional Gross Domestic Product in Samtskhe-Javakheti was $49 \%$ in $2015^{20}$. The most important agricultural products of the region are potato, barley, oats, rye and vegetable ${ }^{21}$. The poor economic conditions and lack of educational opportunities also have pernicious results in direct investments. The leading financial enterprise of the region is Georgia Glass and Mineral Waters Company. However, the company operates in Borjomi, where overwhelming majority of the population are ethnic Georgians, not Armenians ${ }^{22}$.

\section{Map 4: Districts of Samtskhe-Javakheti Region}

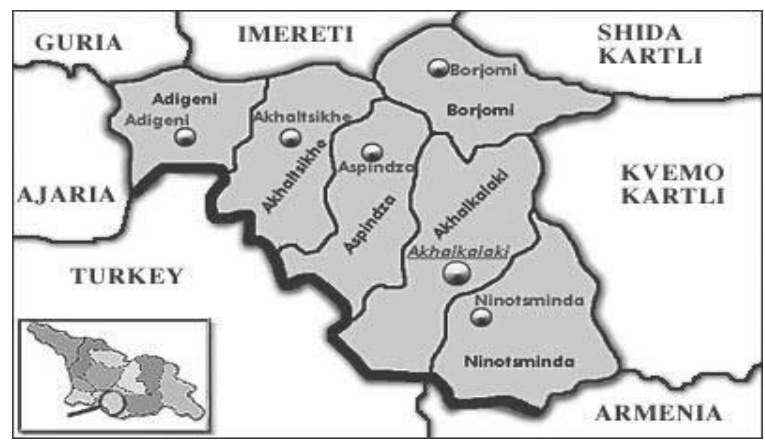

Source: http://www.eurasianet.org/georgia/samtskhe/glance.html.

Thirdly, the Russian Federation should also be considered as an influential factor in the possible turmoil scenarios regarding Samtskhe-Javakheti. The basic reason behind ongoing Russian influence in the region is simply Russia's military and economic links. Russian military presence in the region - which started in 1848 after the Russian conquest - had been heightened since the inception of the Cold War. The Soviet army and its special services were heavily concentrated in the Akhalkalaki district of the region in the $147^{\text {th }}$ Motor Rifle Division ${ }^{23}$. Related to its strategic importance, Javakheti was declared as a closed military zone. Foreigners were barred from entering the area and Soviet citizens needed an official permit to visit Javakheti ${ }^{24}$. At 
Soviet times, the majority of the Samtskhe-Javakheti residents had a strong reliance to the Akhalkalaki military base for security needs, for employment and other social services ${ }^{25}$. In this context, Jonathan Wheatley rightfully asserts that "... in Javakheti, it was not the Georgian state that provided public goods to the local population but the $62^{\text {nd }}$ Divisional Russian base located in the town of Akhalkalaki..."26.

The Russian Federation formally closed its Akhalkalaki base in 2007 long after the OSCE İstanbul Summit of 1999, when the Georgian and Russian sides came to an agreement on the closure $^{27}$. However, the detrimental impacts of the closure on regional employment and agriculture sector became a newly emerged destabilizing factor. It should be noted that, Samtskhe-Javakheti's unemployment rates have been considerably high (more than $80 \%$ ) especially since the closure of the Russian base (62 ${ }^{\text {nd }}$ Divisional Russian Base $)^{28}$ and more and more Samtskhe-Javakheti Armenians prefer exploiting seasonal job opportunities in the Russian Federation $^{29}$. The agriculture sector in the region also suffered from the closure, because the Russian base was the basic market for local agricultural products ${ }^{30}$. In sum, rising economic discontent following the closure of the base and increasing seasonal labor migration towards the Russian Federation paved the way for sympathy of Javakheti Armenians towards the Russian state $^{31}$. In this context, Russia's decision to stop the flow of energy to Ukraine in 2006 and 2009 winters, the Russo-Georgian War of 2008 and contiguous annexation of Crimea by the Russian Federation triggered European perception of insecurity in terms of energy.

\section{The Pillars of EU's Policy towards the Region and EU's Effectiveness}

\section{Full Support to Georgian Territorial Integrity}

As answer to its fears of insecurity in terms of energy, the European Union has continuously implemented a one-dimensional Georgian policy since the official inauguration of the BTC pipeline. The cornerstone of European Union's South Caucasus policy has always been the discourse of maintaining Georgia's territorial integrity. For instance, the European Union remained committed to the policy of non-recognition of Abkhazia's and South Ossetia's unilateral declarations of independence ${ }^{32}$. After the Russo-Georgian War of 2008 and relating to the presidential elections held in Abkhazia and South Ossetia, the European Union institutions made some declarations reiterating the European Union's full support for sovereignty and territorial integrity of Georgia ${ }^{33}$.

It is without question that the policy of defending Georgian territorial integrity is mandatory to establish regional stability in the East-West Energy Corridor. However, in some instances Tbilisi-centered policy of the European Union resulted in a disguised support for exclusionist nationalist and religious policies of Georgian state authorities. As Tonoyan points out, dominant segments of Georgian nationalism follow Zviad Gamsakhurdia's ${ }^{34}$ path to define minorities like Armenians as "temporary guests", or "renters" ${ }^{35}$. In this context, starting from Saakashvili's presidency, identity politics line increased its dominance in Georgian state administration. Saakashvili administration initiated a state program based on promoting Georgian language as the state language for public administration and education ${ }^{36}$. In parallel with this measure, poor knowledge of Georgian language increasingly became a factor in losing state-paid job opportunities ${ }^{37}$ or in failing national entry exams for Georgian universities ${ }^{38}$. Likewise, Armenians have been poorly represented in Georgian parliament, in bureaucratic cadres and Samtskhe-Javakheti's municipalities ${ }^{39}$. Armenian perception of Saakashvili's policies should clearly be seen in 2009 visit of Saakashvili to Armenia. During his visit, Armenian demonstrators accused Saakashvili of committing a cultural genocide on the Armenians in Javakheti ${ }^{40}$. It should be noted that the European Union did not actively exert pressure on Georgia for the ratification of the European Charter for Minority and Regional Languages that should guarantee Armenian language rights in state services and education ${ }^{41}$.

The European Union also did not actively participate in eliminating religious discrimination against minority groups in Georgia. According to Article 9 of the Georgian 
constitution, Georgian state announces absolute freedom in religious belief but simultaneously recognizes special importance of the Georgian Orthodox Church in Georgian history ${ }^{42}$. Some privileges such as specific tax exemptions, recognition of the ownership on all the Orthodox churches, exemptions of clergymen from military service, educational exemptions such as voluntary teaching of Orthodox Christianity in the educational establishments, recognition of diplomas, degrees and titles bestowed by church institutions, were granted by the Georgian state $^{43}$. The status of the Georgian Church as the only spiritual institution that has governmental back caused some protests in the Armenian community ${ }^{44}$. Correspondingly, the Russian Federation became reimagined as a "safe harbor" by increasing number of Javakheti Armenians.

\section{European Union's Association Agreement with Georgia}

Related to Romania's and Bulgaria's accession to the European Union, starting from 2007 the European Union increasingly drew attention to the Black Sea region. In this context, apart from its neighborhood policy, the European Union firstly initiated a strategy called "Black Sea Synergy - a New Regional Cooperation Initiative" at a joint meeting of European Union and Black Sea foreign ministers in 2008. Secondly in 2009, at Prague summit, the European Union launched its Eastern Partnership initiative with Armenia, Azerbaijan, Belarus, Moldova, Ukraine and Georgia $^{45}$. The European Union-Georgian Association Agreement of June 2014 was signed throughout this background. This agreement brings forth important implications for the SamtskheJavakheti region and in the final analysis for the European energy security.

\section{Free Trade Area}

The most significant impact of the Association Agreement on Georgia was its determination on economic integration. In this context, Article 22 of the agreement states that: "the parties shall establish a free trade area starting from the entry into force of this Agreement in accordance with the provisions of this Agreement and in conformity with Article XXIV of the General Agreement on Tariffs and Trade" ${ }^{96}$. On June 27, 2014, Deep and Comprehensive Free Trade Agreement was signed between the European Union and Georgia in line with the previous association agreement ${ }^{47}$. It was estimated that, the Free Trade Agreement would bring many economic benefits to Georgia by giving Georgian companies access to the European Union's single market $^{48}$.

The estimated positive impacts of the free trade agreement were jeopardized with a Russian effort to suspend its free trade agreement with Georgia. In 1994 a free trade regime had been established between the Russian Federation and Georgia following the accession of Georgia to the Commonwealth of Independent States (CIS) ${ }^{49}$. However, despite the establishment of the regime, in 2006 Russia introduced a complete trade embargo on almost all goods made in Georgia after Georgia had arrested six Russian citizens and expelled them from Georgia on espionage charges ${ }^{50}$. Russia lifted the restrictions on Georgian goods in 2013 following the negotiations with newly elected Georgian government led by Georgian Dream Party ${ }^{51}$. Ultimately in July 2014, Russia's Ministry for Economic Development and Trade drafted a decree on suspending the Russian-Georgian Free Trade Agreement of $1994^{52}$.

In sum, the introduction of a free trade agreement between the European Union and Georgia resulted in Russia's suspension of its free trade agreement with Georgia. The introduction of the European Union-Georgia Free Trade Agreement and the suspension of the Russia-Georgia agreement would have detrimental results in Samtskhe-Javakheti, depending on the region's strong trade links with non-EU states such as Armenia and the Russian Federation. Firstly, it is expected that with the implementation of the Association Agreement tougher border control measures would limit already existed illegal export of oil from Georgia to Armenia through Samtskhe-Javakheti. As Overland asserts, the petrol stations in Samtskhe-Javakheti have always been an important tool of the Javakheti Armenians' informal economy ${ }^{53}$. Most Javakheti Armenians earned their money through their role as conduits for exporting cheap oil from Azerbaijan to the Armenian market. In other words, hostile relations between Armenia and Azerbaijan after the outbreak of military conflict over Nagorno-Karabagh created an illegal business opportunity for Javakheti Armenians. Correspondingly, tougher border controls would 
diminish the illegal trade and create additional financial problems and unemployment risks for Javakheti Armenians ${ }^{54}$. Secondly, up to 20 percent increase in Russian custom duties on products from Georgia is expected following the suspension of the Russia-Georgia free trade regime ${ }^{55}$. The increase in custom duties would have negative impacts on the export of Samtskhe-Javakheti products such as Borjomi mineral water, potatoes and wine.

What is more, Armenia officially joined Russia-led customs union (The Eurasian Economic Union) in January $2015^{56}$. As Zurab Gogoberidze points out, “...these competing trade bloc loyalties will most likely challenge Georgia's and Armenia's ability to maintain their bilateral economic relations..." ${ }^{" 57}$. Armenian accession to the Eurasian Economic Union should create additional risks to Samtskhe-Javakheti region's trade relations with Armenia.

\section{Visa Regime}

In mid 2000s, apart from its disputed embargo, the Russian Federation launched a visa regime for Georgian citizens including Javakheti residents working seasonally in the Russian Federation. Correspondingly, some Javakheti Armenians worked for retaining Armenian passports in order to break the Russian visa barrier, because the Armenian citizens did not need visas to enter Russia ${ }^{58}$. Some researchers suggest that Moscow is also issuing Russian passports to Javakheti Armenians ${ }^{59}$. Under those circumstances, European Union's Association Agreement with Georgia generated significant ramifications for Samtskhe-Javakheti Armenians' citizenship and visa problems.

According to Article 12 of the Georgian Constitution, a citizen of Georgia shall not at the same time be a citizen of another state except in cases where Georgian citizenship has been granted to a foreign citizen by the President of Georgia ${ }^{60}$. According to Article 32 of the Georgian Law on Citizenship, a person shall lose citizenship of Georgia if he/she adopts the citizenship of another state ${ }^{61}$. It should be noted that, despite Georgian constitutional ban on dual citizenship, in practice Georgian authorities had almost always disregarded this constitutional provision. When Georgia started negotiations with the European Union about a visa-free regime, thanks to strict border controls, people who had two passports started to be detected easily and deprived of Georgian citizenship automatically. As a result, most of the Armenians of the Samtskhe-Javakheti region who possessed two passports lost Georgian passports and became aliens in Georgia. Concomitantly, a revision was made in Georgian Law on the Legal Status of Aliens and Stateless Persons in accordance with the European Union legislation in September 2014. According to the new law, a foreigner can continuously stay in Georgia no more than 90 days. Previously, the time period was 360 days. The only way for foreigners to continue to stay in Georgia is to leave the country and obtain new visa because, according to the new law, visas are no longer issued by the Public Service Development Agency of the Ministry of Justice of Georgia. Visas are issued by only the diplomatic representations or consulates of Georgia abroad. This means, every 3 month, Javakheti Armenians who have Russian or Armenian passports have to move to Erivan, acquire new visa and come back to Georgia ${ }^{62}$. Daily life difficulties of Javakheti Armenians should easily become a factor in increasing their alienation from Europe's institutions and in the final analysis diminish Europe's energy security.

\section{Conclusion}

In this paper, it is argued that, as answer to its fears of insecurity in terms of energy, the European Union has continuously implemented a one-dimensional and futile Georgian policy since the official inauguration of the BTC pipeline. The cornerstone of European Union's South Caucasus policy has always been the discourse of maintaining Georgia's territorial integrity. It is without question that the policy of defending Georgian territorial integrity is mandatory to establish regional stability in the East-West Energy Corridor. However, in some instances Tbilisi-centered policy of the European Union resulted in a disguised support for exclusionist nationalist policies of Georgian state authorities. Correspondingly, increasing number of Javakheti Armenians started to reimagine the Russian Federation as a "safe harbor". This means, the European Union's 
initiatives to maintain its energy security ironically turned into new factors in endangering its energy security.

The European Union managed to get alternative energy sources and successfully accomplished the diversification of their routes; however failed to establish instrumental mechanisms to avoid political and economic instabilities regarding a strategically important

18 transit region: Samtskhe-Javakheti. The European Union simply lacks a comprehensive regional plan related to the sociological and economic realities of that region.

\section{Notes}

1 "European Energy Consumption Level Falls to 20-Year Low", The Guardian, February 9, 2015, http://www. theguardian.com/environment/2015/feb/09/eu-energy-consumption-level-falls-to-20-year-low, Accessed July 24, 2015. For the consumption statistics, see. "BP Statistical Review of World Energy- June 2015", $\quad B P, \quad$ http://www. bp.com/content/dam/bp/pdf/Energy-economics/statistical-review-2015/bpstatistical-review-of-world-energy-2015-full-report.pdf, Accessed July 24, 2015.

2 "Communication from the Commission to the European Parliament and the Council - European Energy Security", Official Website of the European Union, 2014, http://eur-lex.europa.eu/legalcontent/EN/ALL/?uri= CELEX:52014DC0330\&qid=1407855611566, Accessed September 18, 2015.

${ }^{3}$ Daniel K. Jonsson et.al., "Energy Security Matters in the EU Energy Roadmap" Energy Strategy Reviews, 6, (2015): 48.

4 "Energy", Official Website of the European Union, http://europa.eu/pol /ener/index_en.htm, Accessed July 24, 2015.

${ }^{5}$ Dimitrios Mavrakis, Fotios Thomaidis, and Ioannis Ntroukas, "An Assessment of the Natural Gas Supply Potential of the South Energy Corridor from the Caspian Region to the EU". Energy Policy, 34, 13 (2006): 1671 .

6 "Communication from the Commission to the European Parliament and the Council - European Energy Security", Official Website of the European Union, 2014, http://eur-lex.europa.eu/legalcontent/EN/ALL/?uri= CELEX:52014DC0330\&qid=1407855611566, Accessed September 18, 2015.

${ }^{7}$ Edward H. Christie, "Energy Vulnerability and EU-Russia Energy Relations" Journal of Contemporary European Research, 5, 2 (2009): 276.

8 Tracey C. German, "Corridor of Power: The Caucasus and Energy Security", Caucasian Review of International Affairs, 2, 2 (2008): 65.

${ }_{9}^{9}$ Philip D. Rabinowitz et.al., (2004). "Geology, Oil and Gas Potential, Pipelines, and the Geopolitics of the Caspian Sea Region", Ocean Development and International Law, 35, 1 (2004): 26.

${ }^{10}$ Mark Tran, "Q\&A: The Baku-Tbilisi-Ceyhan Pipeline", The Guardian, May 22, 2005, http://www.the guardian.com/business/2005/may/26/businessqandas.Oilandpetrol, Accessed July 25, 2015.

11 "Baku-Tbilisi-Ceyhan Pipeline", BP Official Website, http://www.bp.com/en_az/caspian/operationsprojects /pipelines/BTC.html, Accessed September 19, 2015.

12 "Caspian Pipeline is Declared Open", BBC News, July 13, 2006, http://news.bbc.co.uk/2/hi/europe/5175676. stm, Accessed July 25, 2015.

13 "Contract for South Caucasus Pipeline's Expansion Signed in Azerbaijan", Trend News Agency, May 26, 2014, http://en.trend.az/business/energy/2278377.html, Accessed September 19, 2015.

14 "Turkey, Azerbaijan Break Ground for Trans-Anatolian Gas Pipeline”, Hürriyet Daily News, September 20, 2014, http://www.hurriyetdailynews.com/turkey-azerbaijan-break-ground-for-trans-anatolian-gaspipeline.aspx? PageID=238\&NID=71968\&NewsCatID=348, Accessed September 19, 2015. "TAP Project Development Schedule" Trans-Adriatic Pipeline Official Website, http://www.tap-ag.com/thepipeline/project-timeline, Accessed January

Accessed September 19, 2015.

15 Besim Özcan, "1828-1829 Osmanl1-Rus Harbi’nde Erzurum Eyaleti’nden Rusya'ya Göçürülen Ermenilerin Geri Dönüşlerini Sağlama Faaliyetleri” A.Ü. Türkiyat Araştırmaları Enstitüsü Dergisi, 46 (2011): 199.

16 Voitsekh Guretski, "The Question of Javakheti", Caucasian Regional Studies, 3, 1 (1998): http://poli.vub.ac. be/publi/crs/eng/0301-05.htm, Accessed September 23, 2015.

${ }^{17} \mathrm{http}: / / \mathrm{www} . g e o s t a t . g e / \mathrm{cms} /$ site_images/_files/english/census/2002/03\%20Ethnic\%20Composition.pdf,

Accessed September 23, 2015. 
18 "Georgia: The Javakheti Region's Integration Challenges", International Crisis Group Policy Briefing, 63, (May 23, 2001): 2. European Yearbook of Minority Issues Volume 3, (Leiden: Martinus Nijhoff Publishers, 2005), 391. Frederik Coene, The Caucasus - an Introduction, (Oxon: Routledge, 2010), 159.

19 Samtskhe-Javakheti Regional Development Strategy, (Tbilisi: Ministry of Regional Development and Infrastructure of Georgia, 2013), 7-9.

${ }^{20}$ Revaz Tolordava et.al., (2015). "Samtskhe-Javakheti Agriculture Sectors Development and Its Ecological Problems", Earth Sciences, 4, 5-1 (2015): 42.

${ }^{21}$ Igor Bondyrev, Zurab Davitashvili, and Vijay P. Singh, The Geography of Georgia - Problems and Perspectives, (New York: Springer, 2015), 173. Samtskhe-Javakheti Regional..., 7-9.

${ }^{22}$ Jonathan Wheatley, The Integration of National Minorities in the Samtskhe-Javakheti and Kvemo-Kartli Provinces of Georgia, (Flensburg: European Centre for Minority Issues, 2009), 10.

${ }^{23}$ Gevorg Melikyan, "The Dynamics of Military Basing in the South Caucasus", in Military Bases: Historical Perspectives, Contemporary Challenges, ed. Luis Rodrigues and Sergiy Glebov, (Lisbon: IOS Press, 2009), 189.

${ }^{24}$ Indra Overland, "The Integration of Non-Russian Servicemen in the Imperial, Soviet and Russian Army", The Journal of Power Institutions in Post-Soviet Societies, 10 (2009): 3.

${ }^{25}$ Svante E. Cornell, Small Nations and Great Powers - a Study of Ethnopolitical Conflict in the Caucasus, (London and New York: Routledge, 2001), 169.

${ }^{26}$ Jonathan Wheatley, J. "Managing Ethnic Diversity in Georgia: One Step Forward, Two Steps Back" in War and Revolution in the Caucasus: Georgia Ablaze, ed. Stephen F. Jones, (London: Routledge, 2010), 34.

${ }^{27}$ Kornely Kakachia, "The End of Russian Military Bases in Georgia: Social, Political and Security Implications of Withdrawal", in Military Bases: Historical Perspectives, Contemporary Challenges, ed. Luis Rodrigues and Sergiy Glebov, (Lisbon: IOS Press, 2009), 199-200.

${ }^{28}$ Charlotte Hille, State Building and Conflict Resolution in the Caucasus. (Leiden and Boston: Brill, 2010), 241.

29 Archil Abashidze, "Javakheti: One Year After the August War", Caucasus Institute for Peace, Democracy and Development Policy Review, (October 2009): 6.

30 "Georgia: The Javakheti Region's Integration Challenges", International Crisis Group Policy Briefing, 63, (May 23, 2011): 2.

31 Luke Coffey, "Russia's Next Acquisition”, Al Jazeera, January 17, 2015, http://www.aljazeera.com/indepth/ opinion/2015/01/russia-caucasus-georgia-armeni2015114111654383153.html, Accessed January 9, 2016.

32 "EU Relations with Georgia" European Union External Action, http://eeas.europa.eu/georgia/index_en.htm, Accessed October 8, 2015.

33 Paruyr Hovhannisyan, "Evolution of the EU Position vis-à-vis the Nagorno-Karabagh Conflict" in Europe's Next Avoidable War: Nagorno-Karabagh, ed. Michael Kambeck and Sargis Ghazaryan, (New York: Palgrave Macmillan, 2013), 170. Rikard Bengtsson, The EU and the European Security Order: Interfacing Security Actors, (New York: Routledge, 2009), 75. "EU Fully Supports the Sovereignty and Territorial Integrity of Georgia" Newsday Georgia, September 23, 2015, http://newsday.ge/new/index.php/en/component/k2/item/ 7205-eu-fully-supports-the-sovereignty-andterritorial-integrity-of-georgia, Accessed October 18, 2015.

${ }^{34}$ Zviad Gamsakhurdia was a romantic nationalist dissident in Soviet-era and the first elected president of the independent Georgian state.

${ }^{35}$ Artyom Tonoyan, "Rising Armenian-Georgian Tensions and the Possibility of a New Ethnic Conflict in the South Caucasus", Demokratizatsiya, 18, 4 (2010): 297.

36 "Georgia: The Javakheti Region's..., 2.

${ }^{37}$ Theresa Freese, "Story: Friends at Dinner, Foes at Politics?", Eurasianet.org, http://www.eurasianet.org/ georgia/samtskhe/story.html, Accessed October 14, 2015.

${ }^{38}$ Overland, "The Integration of...., 46.

39 "The Ethnic Armenian Minority of Georgia - Report by the Yerkir Union of Non-Governmental Organizations for Repatriation and Settlement", Yerkir, September 17, 2007, http://tbinternet.ohchr.org/Treaties/ CCPR/Shared\%20Documents/GEO/INT_ CCPR_NGO_GEO_91_8921_E.pdf, Accessed October 14, 2015.

${ }^{40}$ Alexander Sosnowski, The Georgia Syndrome Non-Fiction, (Rottenburg: Mauer Verlag, 2012 ), 87.

41 "Armenians Seek Language Right in Georgia", CRS, 680, (March 22, 2013), http://www.refworld.org/docid/ 5154150e2.html, Accessed January 10, 2016.

${ }^{42}$ Christopher P.M. Waters, Counsel in the Caucasus - Professionalization and Law in Georgia, (Leiden: Springer, 2004), 56. 
${ }^{43}$ Study of Religious Discrimination and Constitutional Secularism in Georgia, (Tbilisi: Tolerance and Diversity Institute, 2014), 16-31.

44 "Armenians Protest Georgian Neglect of Historic Churches", Armenian Online, November 30, 2009, http://www.armenia.com.au/news/Armenia-News/English/657/Armenians-protest-Georgian-neglect-ofhistoric-churches/310, Accessed October 14, 2015).

| $10 \quad{ }^{45}$ Esra Hatipoğlu, "Yorgun AB'nin Komşularla İmtihanı: Karadeniz Bölgesi ve Avrupa Birliği”, Orta Asya ve Kafkasya Araştırmaları, 8, 16 (2013): 2-3. "EU Relations with Eastern Partnership", European Union External Action, http://eeas.europa.eu/eastern/index_en.htm, Accessed October 16, 2015.

46 "Association Agreement between the European Union and the European Atomic Energy Community and Their Member States, of the One Part, and Georgia, of the Other Part", Official Journal of the European Union, (August 30, 2014): 14.

47 "Russia Hits Back at Georgia over Trade Agreement with European Union", Radio Free Europe Radio Liberty, August 2, 2014, http://www.rferl.org/content/georgia-russia-eu-agreement-freetrade/25478788.html, Accessed October 17, 2015.

48 "EU Relations with Georgia", European Union External Action, http://eeas.europa.eu/georgia/index_en.htm, Accessed October 8, 2015.

${ }^{49}$ Giorgi Menabde, "Is Russia Resuming a Trade War Against Georgia?", Eurasia Daily Monitor, 11, 4 (August 6, 2014), http://www.jamestown.org/single/?tx_ttnews\%5Btt_news\%5D=42719\&no_cache=1\#.ViFfQLVUBg U, Accessed October 16, 2015.

${ }^{50}$ Niklas Nilsson, "Georgia's Rose Revolution: The Break with the Past", in The Guns of August 2008 Russia's War in Georgia, ed. Svante E. Cornell and S. Frederick Starr, (New York: Routledge, 2015), 101.

51 Giorgi "Is Menabde, Russia Resuming...", http://www.jamestown.org/single/?tx_ttnews\%5Btt_news\%5D=42719\&no_cache=1\#.ViFfQLVUBgU.

52 "Russia Hits Back at...", http://www.rferl.org/content/georgia-russia-eu-agreement-freetrade/25478788.html.

${ }^{53}$ The situation was the same in South Ossetia. Before 2004, 70-80 \% of South Ossetia's fiscal income had come from illegal trade. For details see. Niklas Nillson, "Georgia's Conflicts: Abkhazia and South Ossetia", in Conflict, Crime, and the State in Postcommunist Eurasia, ed. Svante Cornell and Michael Jonsson, (Philadelphia: University of Pennsylvania Press, 2014), 117-119. Merve İrem Yapıcı, "Kafkasya'nın Sorunlu Bölgesi: Güney Osetya”, Orta Asya ve Kafkasya Araştırmaları, 2, 3 (2007): 83-84.

${ }^{54}$ Overland, "The Integration of....", 52-53.

55 Giorgi "Is Menabde, Russia Resuming...", http://www.jamestown.org/single/?tx_ttnews\%5Btt_news\%5D=42719\&no_cache=1\#.ViFfQLVUBgU.

56 "Armenia Joins Russia-led Eurasian Economic Union", The Moscow Times, January 2, 2015, http://www.the moscowtimes.com/business/article/armenia-joins-russia-led-eurasian-economicunion/514035.html, Accessed October 18, 2015.

${ }^{57}$ Giorgi Menabde, "Georgia and Armenia Try to Maintain Friendship Across Geopolitical Barriers", Eurasia Daily Monitor, 11, $225 \quad$ (December $17, \quad$ 2014), http://www.jamestown.org/programs/edm/single/?tx_ttnews\%5

Btt_news\%5D=43212\&cHash=6fa05adae027a8d6809001fc8a7dab23\#.ViK3crVUBgV, Accessed October $17,2015$.

${ }^{58}$ Giorgi Kalatozishvili, "'Passport Difficulties' of Javakheti Armenians Turn Into Political Problem”, Vestnik Kafkaza, February 11，2015, http://vestnikkavkaza.net/analysis/politics/66147.html, Accessed October 17, 2015.

${ }^{59}$ Luke Coffey, "Russia's Next Acquisition", http://www.aljazeera.com/indepth/ opinion/2015/01/russiacauca sus-georgia-armeni-2015114111654383153.html. Eka Janashia, "Moscow Distributes Passports in Georgia", The Central Asia-Caucasus Analyst, May 7, 2014, http://www.cacianalyst.org/publications/fieldreports/item/12966-moscow-distributes-passports-in-georgia.html, Accessed October 18, 2015.

60 "Constitution of the Republic of Georgia", European Commission for Democracy Through Law, May 27, 2004, http://www.venice.coe.int/webforms/documents/?pdf=CDL(2004)041-e, Accessed October 18, 2015.

${ }^{61}$ George Hewitt, A Reassessment of the Georgian-Abkhazian and Georgian-South Ossetian Conflicts. (Leiden: Brill, 2013), 289.

${ }_{62}$ Giorgi Kalatozishvili, “'Passport Difficulties' of Javakheti Armenians...", http://vestnikkavkaza.net/analysis/ politics/66147.html. Zurab Chilingarashvili, "The population of the Javakheti Region Has Had Some Problems since the Visa Regulations Were Imposed". FactCheck, March 9, 2005, http://factcheck.ge/en/article/the-popula tion-of-the-javakheti-region-has-had-problems-since-thevisa-regulations-were-imposed/, Accessed September 19, 2015. 